\title{
Výsledky dlouhodobého screeningu kvality rybničních sedimentů v České republice
}

\section{MAREK BAXA, JANA ŠULCOVÁ, LENKA KRÖPFELOVÁ, JAN POKORNÝ, JAN POTUŽÁK}

\author{
Klíčová slova: sediment - rybník - kovy - polutanty
}

\section{SOUHRN}

Tento článek prezentuje výsledky z dlouhodobého screeningu sedimentů z let 2011-2019. Výsledková databáze aktuálně obsahuje približně 230 lokalit. Více jak 80 \% vzorků sedimentů bylo odebráno z rybníků. V České republice se objem rybničních sedimentů odhaduje přibližně na 200 mil. m³. Jejich kvalita je ovlivněna mnoha faktory. V zemědělství je možné využívat sedimenty splňující legislativní limity dané vyhláškou (č. 257/2009 Sb.) upravující podmínky pro použití sedimentů na zemědělskou půdu.

Zaměřili jsme se na hodnocení vybraných toxických kovů (As, Pb, Zn, Cu, $\mathrm{Hg}, \mathrm{Cd}$ ) a organických polutantů (C10-C40, BTEX, PAU, PCB, DDT). Ze zjištěných výsledků Ize dle průměrných koncentrací seřadit prezentované kovy následovně $\mathrm{Zn}>\mathrm{Cu}>\mathrm{Pb}>\mathrm{As}>\mathrm{Cd}>\mathrm{Hg}$. Nejčastější překročení limitu dle vyhlášky č. 257/2009 Sb. bylo zaznamenáno u kadmia (29 lokalit, tj. 12,8 \%). U organických polutantů nejčastěji překračuje limitní hodnoty vyhlášky 257/2009 Sb. parametr PAU cca 7,6 \%, zejména jako důsledek antropogenního znečištění návesních rybníků. Dále BTEX cca 4,1\%, DDT 1,4\% a PCB cca 1,3\%.

\section{ÚVOD}

Rybníky jsou neoddělitelnou součástí hydrologického systému povrchových vod v České republice. Jsou to umělé, člověkem vybudované vodní ekosystémy, které tvoři důležitý prvek krajiny (obr. 5 a 6). Odhaduje se, že k akvakultuře se využívá přibližně 24000 rybníků a vodních nádrží s celkovou plochou přibližně 51800 ha (Operační program rybářství 2007-2013), jiné odhady hovoří až o zhruba 32000 rybníků [1]. Česká kotlina se dlouhodobě potýká se silnou erozí půdy. Důsledkem je, že rybníky, jako mělké vodní nádrže položené v nejnižších místech daného povodí, jsou rychle zazemňovány. Mocnost sedimentu v českých rybnících je průměrně $40 \mathrm{~cm}$ a celkový objem sedimentů se odhaduje na 200 mil. $\mathrm{m}^{3}$ [2]. O tento objem je snížena jejich akumulační schopnost.

Situace v České republice se nachází ve stavu: 1. nedocenění sedimentů jako suroviny (primární je snaha se ho zbavit a nikoliv využít), 2. poměrně př́ísné legislativy a 3. poměrně nákladné chemické analýzy pro vyloučení zjištění kontaminace sedimentů cizorodými látkami. Hospodařící subjekty tak často při výlovech posouvají sedimenty z rybníka do rybníka stále níže a níže v povodí až do velkých vodních nádrží, kde se těžba usazenin stává velmi nákladnou záležitostí. Cestou navíc obvykle dochází ke kontaminaci sedimentů, a poté již nelze o využití naakumulovaných živin pro jejich recyklaci v zemědělství uvažovat ani teoreticky [3].

Zemědělské půdy v České republice trpí nedostatkem organické hmoty. Jedním z řešení je využití rybničních sedimentů z nádrží jako materiálů s vysokým podílem organické hmoty a minerálních živin (obr. 1). Sedimenty mohou být kontaminované rizikovými prvky a rizikovými látkami, a proto je třeba při jejich

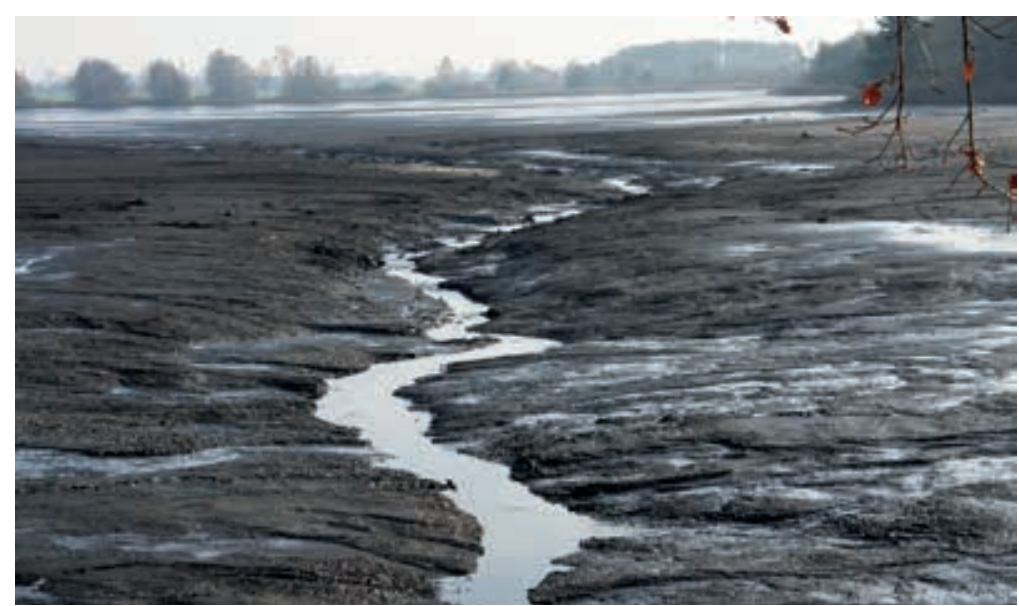

Obr. 1. Vypuštěný rybník s hlavní stokou a typickým rozložením sedimentu Fig. 1. Empty fishpond, central drain and volume of sediment

používání respektovat legislativní rámec, který je koncipován tak, aby jejich používání bylo bezpečné pro půdu, člověka i ostatní složky životního prostředí.

Příspěvek prezentuje výsledky z dlouhodobého screeningu sedimentů z let 2011-2019 z České republiky.

\section{METODIKA ŘEŠENÍ}

\section{Popis lokality}

Vzorkování lokalit je podmíněno plánovaným odbahněním nádrží. Většina rozborů je prováděna na základě objednávek projektantů nebo prímo vlastníků nádrží. Je odebírán reprezentativní vzorek sedimentu z celého, potenciálně těženého materiálu. Lokality nejsou systematicky vybírány, zájmovým územím je celá Česká republika. Jedná se o dlouhodobý a kontinuální screening kvality sedimentů v ČR. Od roku 2011 do poloviny roku 2019 bylo do výsledkové databáze zařazeno téměř 230 lokalit - více jak 80 \% vzorků bylo odebráno z rybníků (např. produkční, návesní, nebeské, v zemědělsky obhospodařované či lesní krajině, prípadně pod bodovými zdroji znečištění). Zbylých 20 \% tvoří pískovny, potoky, slepá ramena či odvodňovací strouhy. Doposud ovzorkované lokality zobrazuje mapa na obr. 2. Nejvíce lokalit je situováno na jihu a jihozápadě Čech. Převážně se jedná o nádrže mělké s průměrnou hloubkou vody cca do $1 \mathrm{~m}$. Velikost vodní plochy činí od 0,5 ha do několika desítek ha. Rozptyl průměrné mocnosti sedimentů ve sledovaných nádržích činí 40-60cm. 


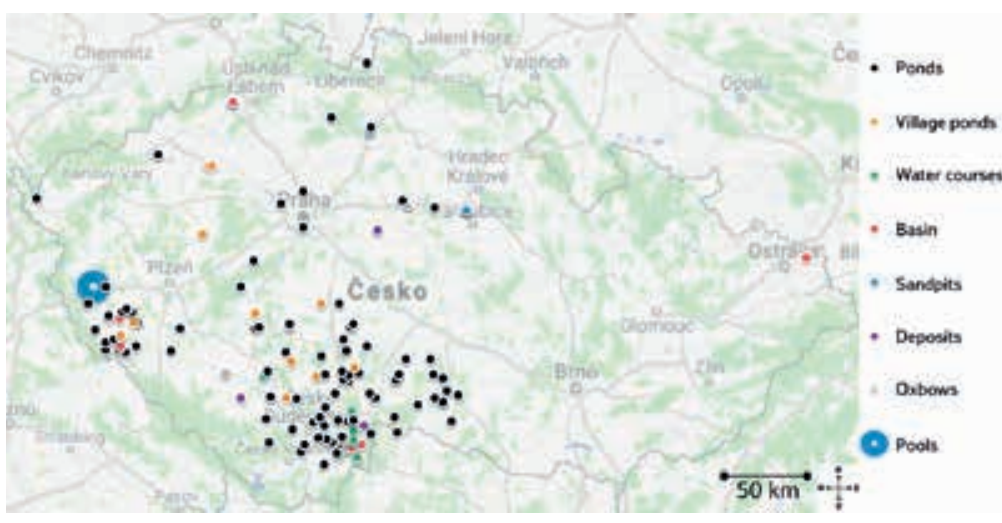

Obr. 2. Mapa České republiky zobrazující odebrané lokality

(zdroj: https://www.google.com/maps)

Fig. 2. Map of Czech Republic with site localities marked

(source: https://www.google.com/maps)

\section{Odběry a analýzy vzorků sedimentu}

Ve zkušební laboratoři ENKI, o. p. s., se zaměřujeme na individuální přístup ke vzorkování jednotlivých nádrží (tzv. vzorkování s úsudkem), a to nejen z hlediska možných bodových zdrojů znečištění (kontaminace toxickými kovy a org. polutanty), ale predevším z hlediska potenciálně těženého objemu sedimentu. To znamená, pokud se v nádrži vyskytuje sediment různého zrnitostního složení, vzorkujeme jej odděleně. Nádrž je tak možné rozdělit do několika částí, aby bylo možno v dalších fázích (při těžbě) se sedimentem nakládat separátně Materiál hrubšího zrnitostního složení lze využít například při stavebních úpravách v rámci oprav tělesa hrází atd. Materiál, který vyhovuje, mj. svým zrnitostním složením, požadované legislativě, lze využít pro zemědělskou produkci.

U sedimentu, který nevyhoví požadované legislativě pouze $v$ jednom parametru a v okolí rybníka se nevyskytují žádné zřejmé zdroje znečištění (jako potenciální faktor kontaminace vzorku), provádíme po dohodě se zákazníkem opakovaný odběr vzorků sedimentů se zaměřením na konkrétní nevyhovující parametr v jednotlivých částech rybníka (včetně vertikálního profilu). Ukazuje se, že v mnoha prípadech není tímto podrobným kontrolním vzorkováním a analýzami sedimentu kontaminace potvrzena.

Odběry vzorků provádíme odběrovou sondou holandského výrobce Eijkelkamp ze dna vypuštěných nebo napuštěných rybníků a nádrží. Zaznamenáváme též mocnost sedimentu, přičemž rozlišujeme tmavší (živinami bohatší sediment) a světlý (minerální sediment). Sonda umožňuje odebrat vertikální profil sedimentu, aniž by došlo ke stlačení vzorku a k porušení jeho stratifikace (obr. 3).

Podle velikosti nádrže odebíráme 1-5 směsných vzorků rybničního sedimentu. Směsný vzorek je tvořen minimálně z 15-30 dílčích vzorků, každý o mocnosti zpravidla 20-100 cm, podle plochy a zanesení nádrže (tzn. celý hloubkový profil sedimentu, viz obr. 3). Jednotlivé body odběru zaměřujeme pomocí přistroje GPS. Vzorky sedimentu homogenizujeme přímo na místě, či v laboratoři a metodou kvartace vybíráme směsný vzorek, který následně odesíláme do akreditované laboratoře k chemickým analýzám [4]. V laboratoři jsou vzorky vysušeny a provedeny analýzy podle legislativou předepsaných norem nebo validovaných postupů. Výluh vzorků byl proveden lučavkou královskou. Stanovení kovů bylo provedeno hmotností spektrometrií na přístroji ICP-MS Stanovení organických polutantů bylo provedeno plynovou chromatografií na prístrojích GC-MS, GC-ECD a GC-FID.

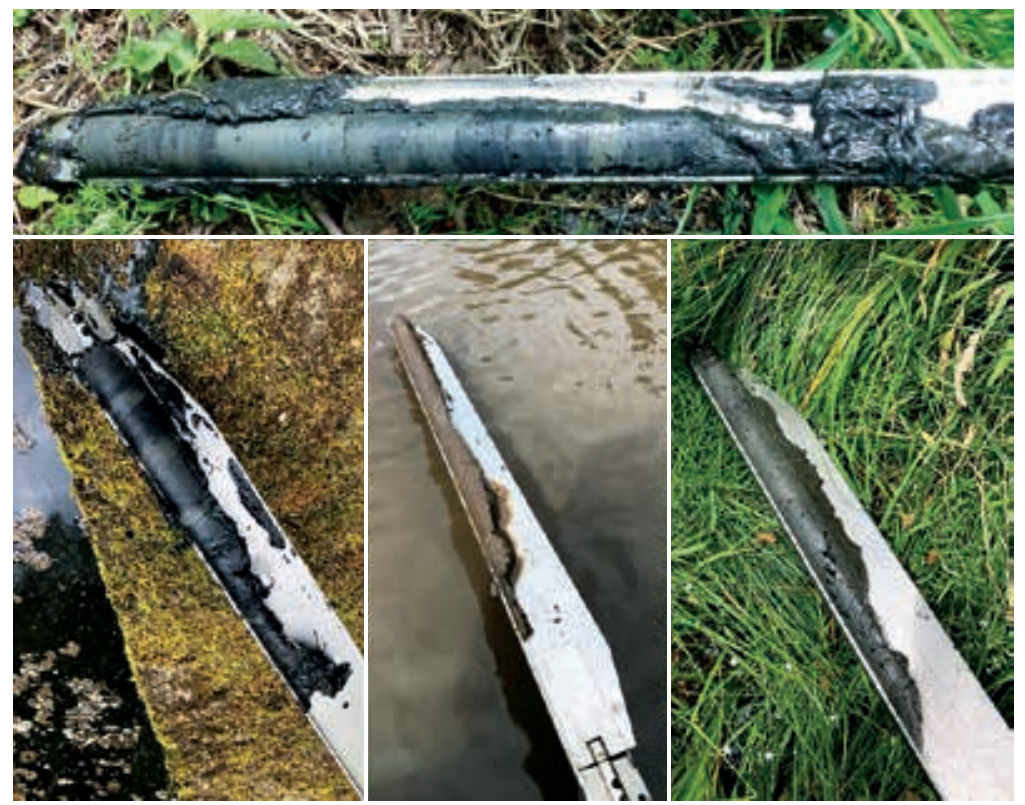

Obr. 3. Odběrová sonda holandského typu Eijkelkamp a rưzné typy struktury sedimentů Fig. 3. Eijkelkamp sediment core sampler and types of sediments structures

\section{Legislativa}

Na rybniční a říční sedimenty je $v$ současné době (z hlediska legislativy ČR) pohliženo jako na odpad. Vytěžený sediment je možno ukládat na povrchu terénu podle zákona č. 185/2001 Sb., o odpadech, vyhlášky č. 387/2016 Sb [5, 6]. Druhou možností uložení vytěženého materiálu je jeho využití na zemědělském pưdním fondu, a to podle zákona č. 156/1998 Sb., o hnojivech, vyhlášky č. 257/2009 Sb., o používání sedimentů na zemědělské půdě [7, 8]. Třetí možností využití sedimentů je jeho použití jako vstupní suroviny do kompostů. Rozhodujícím ukazatelem pro možnost využití sedimentů je míra jejich kontaminace rizikovými prvky a organickými polutanty.

Prezentované výsledky jsou vyhodnoceny podle vyhlášky č. 257/2009 Sb., o používání sedimentů na zemědělské půdě, přiloha č. 1 [8]. Při překročení limitních hodnot nelze rybniční sediment aplikovat na zemědělskou půdu. $V$ souladu s platnou legislativou byly ve vzorcích sedimentu vyhodnocovány obsahy toxických kovů, organických znečištujuících látek (tabulka 1).

Tabulka 1. Seznam měrených parametrů

Table 1. List of assessed parameters

Kovy Zn, $\mathrm{Ni}, \mathrm{Pb}, \mathrm{As}, \mathrm{Cu}, \mathrm{Hg}, \mathrm{Cd}, \mathrm{V}, \mathrm{Co}, \mathrm{Be}, \mathrm{Cr}$

Organické látky $\quad$ C10-C40, BTEX, PAU, PCB, DDT 

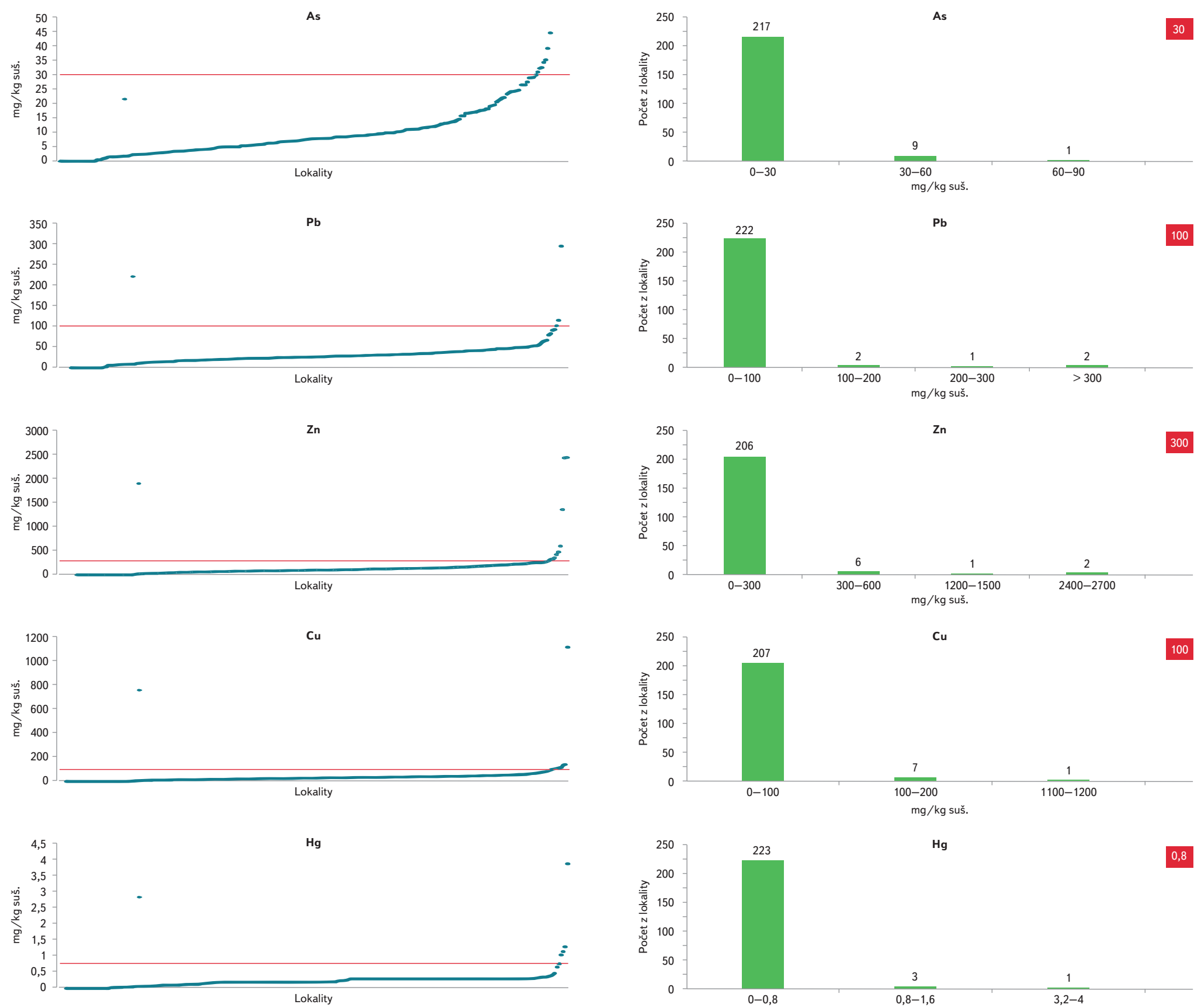

$\mathrm{Hg}$
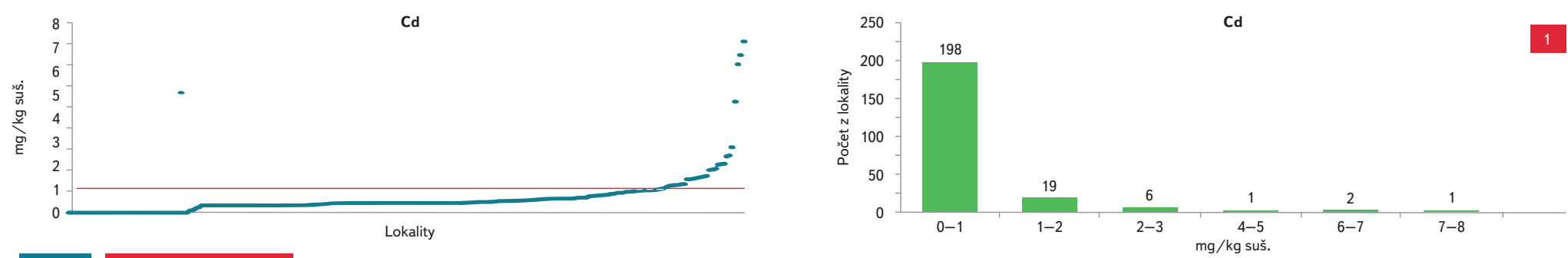

\section{Lokality Limit 257/2009 Sb p. p.z. 1}

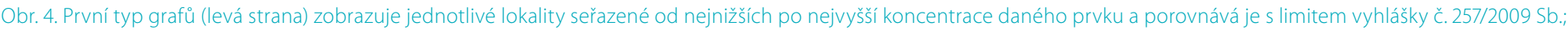
druhý typ (pravá strana) grafů zobrazuje na histogramu četností počet lokalit, které splňují daný limit (první sloupec)

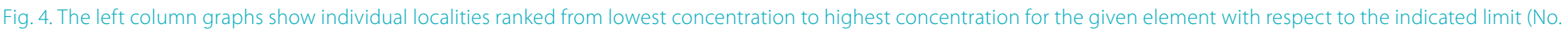

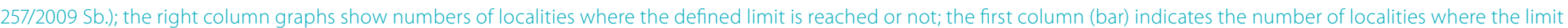
is not exceeded 


\section{VÝSLEDKY A DISKUSE}

\section{Toxické kovy}

Nejčastěji se při analýzách rybničních sedimentů setkáváme s překročením limitů vyhlášky č. 257/2009 Sb. pro toxické kovy. Z výsledkové databáze v textu zmiňujeme pouze vybrané kovy (soubor grafů na obr. 4). Průměrné koncentrace, rozsah (MIN a MAX) a směrodatnou odchylku (SD) uvádíme v tabulce 2.

Problematika výskytu arsenu v půdách a v sedimentech je rozsáhlá, a to nejen $v$ ČR. Hodnoty arsenu mohou být často ovlivněny jeho přirozeným výskytem v prostředí, odkud se může uvolňovat do různých složek ekosystému i antropogenních činností [9]. Geologické podloží ČR obsahuje sloučeniny bohaté na arsen. $\vee$ mnoha případech jsou sloučeniny (asi nejvíce arsenopyrit) vázány na oblasti s výskytem hnědého uhlí. V príhraničním pásmu ČR je řada významných těžebních oblastí, v jejichž okolí jsou prokazatelně zvýšeny pozad’ové hodnoty As [9]. Průměrná pozad'ová hodnota pro ČR je $7,5 \mathrm{mg} / \mathrm{kg}$ sušiny [10]. Z grafů na obr. 4 je zřejmé, že na desíti lokalitách (tj. 4,4 \%) byly zjištěny hodnoty As vyšší, než povoluje citovaná vyhláška č. 257/2009 Sb. Z toho vyplývá, že
Tabulka 2. Koncentrace toxických kovư v sedimentech z let 2011-2019 (prưměr, MIN, MAX) Table 2. Concentration of toxic metals in sediments during the period 2011-2019 (MEAN, MIN, MAX)

\begin{tabular}{lllllll}
$\mathbf{2 0 1 1 - 2 0 1 9}$ & As & $\mathbf{P b}$ & $\mathbf{Z n}$ & $\mathbf{C u}$ & $\mathbf{H g}$ & $\mathbf{C d}$ \\
\hline $\begin{array}{l}\text { Průměr } \\
\text { (mg/kg suš.) }\end{array}$ & $\mathbf{1 0 , 3}$ & $\mathbf{3 1 , 0}$ & $\mathbf{1 5 1 , 6}$ & $\mathbf{3 9 , 7}$ & $\mathbf{0 , 3}$ & $\mathbf{0 , 6}$ \\
\hline SD & 9,2 & 24,2 & 251,5 & 77,6 & 0,3 & 0,9 \\
\hline Min (mg/kg suš.) & 0,003 & 0,001 & 0,051 & 0,010 & 0,001 & 0,001 \\
\hline Max (mg/kg suš.) & 65,4 & 296 & 2450 & 1120 & $\mathbf{3 , 9}$ & $\mathbf{7 , 2 5}$ \\
\hline $\mathbf{N}$ & $\mathbf{2 2 4}$ & $\mathbf{2 2 4}$ & $\mathbf{2 1 4}$ & $\mathbf{2 1 4}$ & $\mathbf{2 2 1}$ & $\mathbf{1 9 9}$
\end{tabular}

více jak 95 \% lokalit splňuje limitní hodnoty výše uvedené vyhlášky. U poloviny vzorkovaných lokalit je koncentrace nižší než 8 mg/kg sušiny (medián). Lze konstatovat, že námi vzorkované lokality vykazují podobné hodnoty v porovnání s průměrnými pozadovými hodnotami As pro ČR.

Tabulka 3. Porovnáni dlouhodobých prưměrných hodnot koncentraci toxických kovů naměřených v České republice rưznými autory s limitními hodnotami uvedenými ve vyhlášce č. 257/2009 Sb. a vjiné světové legislativě

Table 3. Results and comparing with other world limits

\section{Výsledky}

\section{Česká republika}

\section{Studie ENKI, o. p. s. [19]}

(2011-2019), 230 lokalit

Gergel a kol. [2]

(1997-2002), 410 lokalit

Kubík [20]

(1995-2010), 377 lokalit

\section{Limity}

Vyhláška č. 257/2009 Sb. př́loha č. 1 [8]

\begin{tabular}{|c|c|c|c|c|c|c|}
\hline & 30 & 100 & 300 & 100 & 0,8 & 1 \\
\hline \multicolumn{7}{|c|}{ Summary of Guidance - Freshwater Navigation Dredging (1995) [21] } \\
\hline No appreciable contamination (Class A) & - & $<30$ & - & $<16^{*}$ & $<0,1$ & $<0,6$ \\
\hline Moderate contamination (Class B) & - & $30-100$ & - & $16-110^{*}$ & $0,1-4$ & $0,6-10$ \\
\hline High contamination (Class C) & - & $>100$ & - & $>110^{*}$ & $>4$ & $>10$ \\
\hline
\end{tabular}

\section{Compilation of Sediment \& Soil, Standards, Criteria \& Guidelines, Table 4 (1995) [22]}

No effect level

Lowest effect level

Severe effect level

The Decree of Italian Ministry of Enviroment No. 173/2016 (L1) [23]

12

As

10,3

31,0

151,6

138,8

153,8

28,9

Cu

Hg

Cd

sediment $\mathbf{m g} / \mathbf{k g}$ suš.

$\begin{array}{llllll}11,8 & 57,9 & 153,8 & 28,9 & 0,136 & 17,4\end{array}$

\begin{tabular}{lll}
39,7 & 0,252 & 0,6 \\
\hline 64,8 & 0,190 & 0,6 \\
\hline 28,9 & 0,136 & 17,4
\end{tabular}


Vzhledem k vysokému akumulačnímu koeficientu se olovo hromadí nejen $\checkmark$ sedimentech, ale i v biomase mikroorganismů a rostlin [11-14]. Průměrná pozad’ová hodnota pro ČR je 45 mg/kg sušiny [10]. Se zpř́isněním limitů obsahu olova z 50 na 10 g/l v pitné vodě [10] Ize předpokládat, že nebude probíhat další kontaminace složek životního prostředí zejména z aditiv do benzínu (tetraethylolovo) a z olověného vodovodního potrubí. Zatížení z minulosti však v prostředí prèetrvává.

Z grafu na obr. 4 je zrejmé, že na pěti lokalitách (tj. 2,2 \%) byly zjištěny hodnoty Pb vyšší, než povoluje limit vyhlášky č. 257/2009 Sb. Více jak 97 \% lokalit splňuje limitní hodnoty. U poloviny vzorkovaných lokalit je koncentrace nižší než $27,4 \mathrm{mg} / \mathrm{kg}$ sušiny (medián).

Zinek je běžnou součástí hornin, půd a sedimentů [14]. Zinek je mimo jiné obsažen v průmyslových hnojivech jako znečištujuící príměs [11] nebo v rybím krmení [16, 17]. Průměrná pozad’ová hodnota pro ČR je 80 mg/kg sušiny. Graf na obr. 4 ukazuje, že na devíti lokalitách (tj. 4,2 \%) byly zjištěny hodnoty Zn vyšší, než povoluje limit vyhlášky č. 257/2009 Sb. Více jak 95 \% lokalit splňuje limitní hodnoty. U poloviny vzorkovaných lokalit je koncentrace nižší než 108 mg/kg sušiny (medián).

Měd’ se v prrírodním prostředí nejčastěji vyskytuje ve formě sulfidů a chalkosinu. Antropogenním zdrojem mědi jsou odpadní vody z povrchové úpravy kovů a z aplikace některých algicidních preparátů, které se dávkují proti nadměrnému rozvoji řas a sinic [11]. Prưměrná pozad’ová hodnota pro ČR je 25 mg/ kg sušiny. Z grafu na obr. 4 je zřejmé, že na osmi lokalitách (tj. 3,7 \%) byly zjištěny hodnoty Cu vyšší, než povoluje limit vyhlášky č. 257/2009 Sb., tzn. více jak 96 \% lokalit splňuje limitní hodnoty. U poloviny vzorkovaných lokalit je koncentrace nižší než 31 mg/kg sušiny (medián). Např́klad v povodí řeky Lužnice byly naměřeny podobné průměrné koncentrace mědi - 31,46 mg/kg sušiny $[14,18]$.

Hlavním zdrojem výskytu rtuti je ruda cinabarit. Kromě toho rtut doprovází jiné sulfidické rudy. Významným zdrojem antropogenního znečištění je spalování fosilních paliv [11]. Průměrná pozad’ová hodnota pro ČR je 0,2 mg/kg sušiny. Limitní hodnoty Hg dané vyhláškou č. 257/2009 Sb. překračují pouze čtyři lokality (tj. 1,8 \%) - viz obr. 4. Více jak 98 \% lokalit tyto hodnoty splňuje. U poloviny vzorkovaných lokalit je koncentrace nižší než 0,21 mg/kg sušiny (medián).

Kadmium vzhledem ke své chemické podobnosti provází zinek $v$ jeho rudách. Významným antropogenním zdrojem kadmia jsou fosforečnanová hnojiva, aplikace čistírenských kalů v zemědělství [11] a emise ze spalování uhlí [13]. Průměrná pozad'ová hodnota pro ČR je 0,2 mg/kg sušiny.

Graf na obr. 4 ukazuje, že na 29 lokalitách (tj. 12,8 \%) byly zjištěny hodnoty Cd vyšší, než povoluje limit vyhlášky č. 257/2009 Sb. Více jak 87 \% lokalit splňuje limitní hodnoty. U poloviny vzorkovaných lokalit je koncentrace nižší než 0,42 mg/kg sušiny (medián).

Dlouhodobě se studiem kontaminace sedimentů v ČRzabýval Gergel a kol. [2]. Z výsledků v tabulce 3 je zřejmé, že průměry hodnot pro jednotlivé toxické kovy na námi sledovaných lokalitách se s těmito daty shodují. Většina vyhodnocených výsledků je pod limitní hodnotou danou vyhláškou [8]. V porovnání s daty naměřenými Ústředním kontrolním a zkušebním ústavem zemědělským v Brně (ÚKZUZ) [20] se výsledky téměř ve všech parametrech shodují. Výjimku tvoří pouze hodnoty parametru $\mathrm{Pb}, \mathrm{v}$ prípadě dat naměřených ÚKZZUZ jsou hodnoty skoro dvojnásobné. U parametru Cd jsou hodnoty naměřené ÚKZUZ 17x vyšší. Tento rozdíl je bezpochyby zapříčiněn extrémní hodnotou $C d$ v jediném vzorku (1 660 mg/kg sušiny). Medián souboru činí 0,4 mg/kg sušiny.

$\checkmark$ prípadě parametru Cu jsou naopak hodnoty naměřené ÚKZUZ skoro poloviční. V porovnání hodnot s [21] spadají námi naměřené hodnoty do kategorie „Moderate contamination (Class B)“. V porovnání s limity uvedenými v [22] naše hodnoty jen o málo převyšují kategorii Lowest effect level. V př́padě parametrů As, Zn, Cu a Hg se naše hodnoty pohybují mezi kategoriemi Lowest effect level a Severe effect level.

Prezentované výsledky umožňují jednotlivé kovy seřadit podle průměrných hodnot koncentrací následovně $\mathrm{Zn}>\mathrm{Cu}>\mathrm{Pb}>\mathrm{As}>\mathrm{Cd}>\mathrm{Hg}$. Totožné je pořadí prvků z dlouhodobé studie [2]. Studie z Hough Park lake v USA [24] uvádí totožné pořadí Zn > Cu > Pb > As > Cd > Hg. Ústřední kontrolní a zkušební ústav zemědělský [20] publikoval data v průběžné zprávě z let 1995-2010 z dlouhodobého monitoringu rybničních a říčních sedimentů. Z jejich výsledků Ize sledované prvky seřadit následovně: $\mathrm{Zn}>\mathrm{Pb}>\mathrm{Cu}>\mathrm{Cd}>\mathrm{As}>\mathrm{Hg}$. Sarker a kol. [17] z 20 různých sladkovodních akvakulturních rybníků v Bangladéši řadí prvky následovně $\mathrm{Zn}>\mathrm{Pb}>\mathrm{Cd}$. Z publikovaných výsledků z akvakulturních rybníků blízko mangrovových mokřadů v Číně [25] Ize vytvořit následující řadu $\mathrm{Zn}>\mathrm{Pb}>\mathrm{Cu}>\mathrm{Cd}>\mathrm{As}>\mathrm{Hg}$.

\section{Organické látky}

Obdobným způsobem byly hodnoceny látky ze skupiny polycyklických aromatických uhlovodíků (PAU), uhlovodíků C10-C40, skupiny cyklických uhlovodíků (BTEX) a persistentní organické látky (PCB a DDT) - tabulka 4. Ze všech sledovaných lokalit překračovalo limitní hodnoty pouze několik málo procent vzorků BTEX cca 4,1 \%, PAU cca 7,6 \% (zejména u návesních rybníků), u PCB cca 1,3\% a u DDT 1,4\%. Námi naměřená data se téměř shodují s daty naměřenými ÚKZUZ pro parametry PAU, PCB a DDT. Ostatní parametry ÚKZUZ nestanovoval.

Tabulka 4. Statistický prehled sledovaných uhlovodiků z let 2011-2019 a porovnáni s limity podle vyhlášky č. 257/2009 Sb.

Table 4. Concentration (MEAN, MIN, MAX, SD) of hydrocarbons in sediments during the period $2011-2019$

\begin{tabular}{llllll}
$\mathbf{2 0 1 1 - 2 0 1 9}$ & $\mathbf{C 1 0 - C 4 0}$ & BTEX & PAU & PCB & DDT \\
\hline $\begin{array}{l}\text { Limit } \\
\text { (mg/kg suš.) }\end{array}$ & $\mathbf{3 0 0}$ & $\mathbf{0 , 4}$ & $\mathbf{6}$ & $\mathbf{0 , 2}$ & $\mathbf{0 , 1}$ \\
\hline $\begin{array}{l}\text { Průměr } \\
\text { (mg/kg suš. })\end{array}$ & 114 & 0,26 & 5,1 & 0,043 & 0,059 \\
\hline SD & 175 & 0,84 & 30,5 & 0,089 & 0,026 \\
\hline Min (mg/kg suš.) & 2 & 0,04 & 0,1 & 0,005 & 0,005 \\
\hline Max (mg/kg suš.) & 1390 & 8,90 & 421,0 & 1,020 & 0,325 \\
\hline $\mathbf{N}$ & $\mathbf{2 0 0}$ & $\mathbf{2 1 7}$ & $\mathbf{2 2 5}$ & $\mathbf{2 2 5}$ & $\mathbf{1 4 2}$
\end{tabular}

Uhlovodíky C10-C40 indikují kontaminaci ropnými látkami. Jedná se o dosti nespecifický ukazatel, který v sobě zahrnuje jak látky prírodního charakteru, tak látky antropogenního původu. V organickém sedimentu rybníků mohou být jejich zvýšené koncentrace způsobeny bakteriální činností, nebo napríklad i př́tomností a potravní aktivitou chironomidů. Látky, které jsou zahrnuty v tomto parametru, mohou vznikat i autochtonně. Podobně to může být i u cyklických uhlovodíků (BTEX), kdy např́klad toluen či xylen dokáže vznikat přirozenými procesy probíhajícími za nedostatku kyslíku v rybničním sedimentu [26-28].

\section{ZÁVĚR}

Příspěvek shrnuje výsledky koncentrací toxických kovů (As, Pb, Zn, Cu, Hg, Cd) a organických polutantů (C10-C40, BTEX, PAU, PCB, DDT) v sedimentu z cca 230 lokalit v České republice z let 2011-2019.

U toxických kovů nejčastěji překračuje limitní hodnoty vyhlášky č. 257/2009 Sb. parametr Cd (průměr 0,6 0,9 mg/kg sušiny) na 29 lokalitách (12,8 \%), zejména jako důsledek aplikace fosforečnanových hnojiv a čistírenských kalů v zemědělství, Zn (průměr 151,6 \pm 251,5 mg/kg suš.) na devíti lokalitách (4,2 \%), jehož antropogenním původem jsou taktéž zejména průmyslová hnojiva nebo krmiva 
pro ryby, a As (průměr 10,3 \pm 9,2 mg/kg sušiny) na desíti lokalitách (4,4 \%), u kterého může vyšší koncentrace způsobovat jeho zvýšený přirozený výskyt v podloží v ČR.

U organických polutantů nejčastěji prekračuje limitní hodnoty vyhlášky Č. 257/2009 Sb. parametr PAU cca 7,6 \%, zejména jako důsledek antropogenního znečištění návesních rybníků. Dále BTEX cca 4,1%, DDT 1,4% a PCB cca 1,3%.

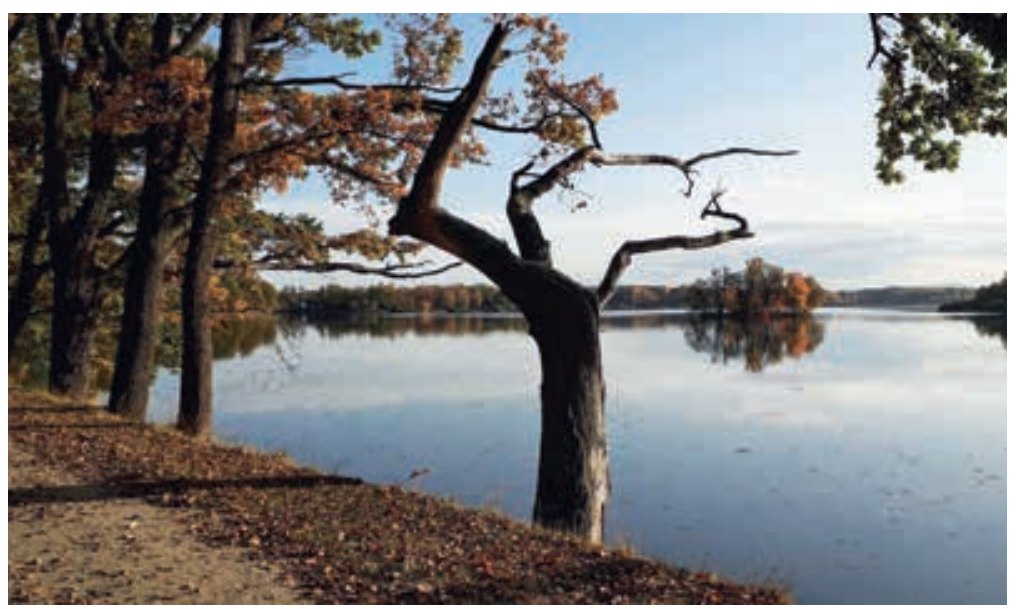

Obr. 5. Pohled na Opatovický rybník v Třeboni

Fig. 5. The Opatovický pond in Třeboň

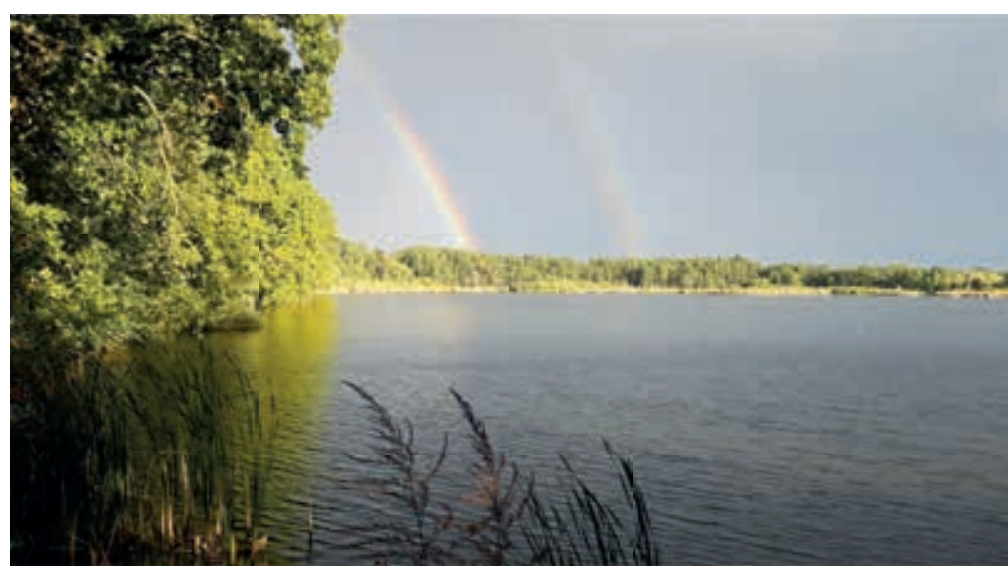

Obr. 6. Pohled na rybník Rod u Lomnice nad Lužnicí

Fig. 6. The Rod pond near Lomnice nad Lužnici

Z datového souboru celkově legislativním podmínkám (vyhláška č. 257/2009 Sb., o používání sedimentů na zemědělské půdě, príloha č. 1 [8]) nevyhovělo 32 \% lokalit. Z toho 21 \% nevyhovělo pouze v jednom parametru a $11 \%$ nevyhovělo ve dvou a více parametrech. Ukazuje se, že z rybničních lokalit bývají nejvíce zatí̌enými návesní rybníky, zatímco sedimenty z rybníků ležících v horních částech povodí vyhovují legislativě častěji.

\section{Poděkování}

Studie byla podpořena z projektu TAČR Centra kompetence TE02000077 - Inteligentní Regiony - Informační modelování budov a sídel, technologie a infrastruktura pro udržitelný rozvoj.

Původní príspěvek byl publikován ve sborníku Rybníky 2019, ISBN 978-80-01-06595-2.

\section{Literatura}

[1] KŘIVÁNEK, J., NĚMEC, J. a KOPP, J. Rybníky v České republice. Praha: Pro Ministerstvo zemědělství ČR vydal Consult, 2012, 303 s. ISBN 978-80-903482-9-5.

[2] GERGEL, J., KOLÁR̆, L., ŠEDIVÝ, V. a HŮDA, J. Rybniční sedimenty, geneze, posuzování, odstraňováni a dalši nakládánís nimi. Přiloha k výzkumné zprávě projektu VaV6304/02, MSM:J06/98:1222200002. 2002, $44 \mathrm{~s}$.

[3] POTUŽÁK, J., DURAS, J., KRÖPFELOVÁ, L., ŠULCOVÁ, J., BAXOVÁ-CHMELOVÁ, I., BENEDOVÁ, Z., SVOBODA, T., NOVOTNÝ, O., POKORNÝ, J. a MARCEL, M. Rybniční sediment a nové možnosti recyklace živin a organických látek v malých povodích - príkladová studie rybník Horusický. Vodníhospodárství, 2017, č. 2, s. 3-10

[4] ŠULCOVÁ, J., BAXA, M., KRÖPFELOVÁ, L. a BAXOVÁ-CHMELOVÁ, I. Monitoring rybničních sedimentů v letech 2011-2017. In: DAVID, V. a DAVIDOVÁ, T. (eds). Rybníky 2017. ČVUT Praha, 2017, s. 144.

\section{[5] Zákon č. 185 /2001 Sb., o odpadech.}

[6] Vyhláška č. 387/2016 Sb., o podmínkách ukládání odpadů na skládky a jejich využívání na povrchu terénu.

[7] Zákon č. 156 /1998 Sb., o hnojivech, pomocných půdních látkách, pomocných rostlinných prípravcích a substrátech a o agrochemickém zkoušení zemědělských pưd (zákon o hnojivech).

\section{[8] Vyhláška č. 257/2009 Sb., o používání sedimentů na zemědělské půdě.}

[9] DRAHOTA, P. and FILIPPI, M. Secondary arsenic minerals in the environment: A review. Environment International 35, 2009, p. 1243-1255.

[10] HAUPTMAN, I., KUKAL, Z. a POŠMOURnÝ, K. Püda v České republice. Praha: Pro Ministerstvo životního prostředí a Ministerstvo zemědělství vydal Consult, 2009, 255 s. ISBN 978-80-903482-4-0.

[11] PITTER, P. Hydrochemie. Praha: Vydavatelství VŠCHT Praha, viii, 4. aktualiz. vyd., 2009, 579 s. ISBN 978-80-7080-701-9.

[12] GEERAERTS, C. and BELPAIRE, C. The effects of contaminants in European eel: A review. Ecotoxicology, 2010, vol. 19, No. 2, p. 239-266

[13] POKORNÝ, J. a KUČEROVÁ, A. Monitoring klimatu a atmosférických depozic v CHKO Třeboňsko. Ekologie a Ekonomika Treboňska po dvaceti letech, 2000, s. 87-99.

[14] POKORNÝ, J., PECHAR, L., RADOVÁ, J., BASTL, J., DRBAL, K., and ŠVEHLA, J. Heavy metals in the floodplain of Lužnice River and in the Naděje fishpond systém. In: KVĚT, J., JENÍK, J., and SOUKUPOVÁ L. (eds.). Freshwater wetlands and their sustainable future. Paris and Boca Raton, 2002, p. 139-253.

[15] Council Directive No. 98/83/EC - on the quality of water intended for human consumption.

[16] BILANDŽIĆ, N., SEDAK, M., DOKIĆ, M., VARENINA, I., KOLANOVIĆ, B.S., BOŽIĆ, D., BRSTILO, M., and ŠIMIĆ, B. Determination of zinc concentrations in foods of animal origin, fish and shellfish from Croatia and assessment of their contribution to dietary intake. Journal of Food Composition and Analysis, 2014, vol. 35, No. 2, p. 61-66.

[17] SARKER, J. Md., KANUNGO, I., TANMAY, M.H., and PATWARY, S.A. Md. A Study on the Determination of Heavy Metals in Sediment of Fish Farms in Bangladesh. Fisheries and Aquaculture Journal, 2016, 7. [18] POKORNÝ, J., PECHAR, L., RADOVÁ, J., BASTL, J., DRBAL, K., and ŠVEHLA, J. Heavy metals in ecosystems of Lužnice River and Naděje fishpond system (Třeboň Biosphere Reserve). In:VYMAZAL, J. (ed.). Nutrient Cycling and Retention in Natural Constructed Wetlands. Leiden, 1999, p. 141-154.

[19] BAXA, M., ŠULCOVÁ, J., KRÖPFELOVÁ, L., POKORNÝ, J., and POTUŽÁK, J. The quality of sediment in shallow water bodies - Long-term screening of sediment in Czech Republic. A new perspective of nutrients and organic matter recycling in agricultural landscapes. Ecological Engineering, 2019, 127, p. 151-159.

[20] KUBíK, L. Monitoring rybničních a říčních sedimentů, 1995-2010. Průběžná zpráva 1995-2010. Ústřední kontrolní a zkušební ústav zemědělský v Brně. Brno, 2011.

[21] Summary of Guidelines for contaminated freshwater sediments, 1995. Publication No. 95-308. Washington State Department of Ecology, Table 1, column F.

[22] Compilation of Sediment \& Soil, Standards, Criteria \& Guidelines, 1995. Quality Assurance Technical Document 7. The Resources Agency, Department of Water Resources, State of California.

[23] Decree of Italian Ministry of Environment No. 173. 15 July 2016. Regulations laying down technical procedures and criteria for the authorization of seabed excavation materials for deposition at sea.

[24] IKEM, A. and ADISA, S. Runoff effect on eutrophic lake water quality and heavy metal distribution in recent littoral sediment. Chemosphere, 2011, 82, p. 259-267.

[25] WU, H., LIU, J., BI, X., LIN, G., FENG, C.C., LI, Z., QI, F., ZHENG, T., and XIE, L. Trace metals in sediments and benthic animals from aquaculture ponds near a mangrove wetland in Southern China. Marine pollution bulletin, 2017, 117, p. 486-491.

[26] FUCHS, G., MOHAMED, M.E.S., ALTENSCHMIDT, U., KOCH, J., LACK, A., BRACKMANN, R., LOCHMEYER, C., and OSWALD, B. Biochemistry of anaerobic biodegradation of aromatic compound. In: RATLEDGE, C. (ed.). Biochemistry of microbial degradation. Springer, Dordrecht, 1994, p. 513-553.

[27] LANGENHOFF, A.A.M. NIJENHUIS, I., TAN, N.C.G., BRIGLIA, M. ZEHNDER, A.J.B., and SCHRAA, G. Characterisation of a manganese-reduction, toluene-degrading enrichment culture, FEMS. Microbiology Ecology, 1997, vol. 24, No. 2, p. 113-125.

[28] MÜLLER, G. Sense or no-sense of the sum parameter for water-soluble "adsorbable organic halogens" (AOX) and "absorbed organic halogens" (AOX-S18) for the assessment of organohalogens in sludges and sediments. Chemosphere, 2003, 52, p. 371-379. 


\section{Autoři}

Ing. Marek Baxa, Ph.D. ${ }^{1}$

凶marek.baxa@prirodou.cz

Ing. Jana Šulcová

凶sulcova@enki.cz

Ing. Lenka Kröpfelová, Ph.D.

凶kropfelova@enki.cz

doc. RNDr. Jan Pokorný, CSc. ${ }^{1}$

凶pokorny@enki.cz

Ing. Jan Potužák ${ }^{2}$

凶jan.potuzak@pvl.cz

${ }^{1}$ ENKI, o. p. s.

${ }^{2}$ Povodí Vltavy, s. p.

Příspěvek prošel lektorským řízením
THE QUALITY OF SEDIMENT IN SHALLOW

WATER BODIES - LONG-TERM SCREENING OF SEDIMENT IN THE CZECH REPUBLIC

\section{BAXA, M.'; SULCOVA, J.'; KROPFELOVA, L.'; POKORNY, J.'; POTUZAK, J. ${ }^{2}$}

${ }^{1} \mathrm{ENKI}$, o. p. s.

2Povodí Vltavy, state enterprise

Keywords: sediment - fishpond - metals - pollutants

This article presents the long-term screening results from the 2011-2019 period. Database of results contains approximately 230 localities. More than $80 \%$ of the samples were taken from fishponds. The Czech Republic fishpond sediment volume estimates amounts to 200 mil. $\mathrm{m}^{3}$. Sediment quality is being impacted by numerous factors. If legislation limits are abided by, sediments may be used. All results have been compared with the Decree No. 257/2009 regulating the conditions for the application of sediment on agricultural land.

We have focused on evaluating toxic metals ( $\mathrm{As}, \mathrm{Pb}, \mathrm{Zn}, \mathrm{Cu}, \mathrm{Hg}, \mathrm{Cd}$ ) and organic pollutants (C10-C40, BTEX, PAH, PCB, DDT). The results reveal that the average concentration of the metals leads to the following ranking: $\mathrm{Zn}>$ $\mathrm{Cu}>\mathrm{Pb}>\mathrm{As}>\mathrm{Cd}>\mathrm{Hg}$. The most frequent excess of the limit listed in Decree No. 257/2009 was reported for cadmium (29 locations, i.e. 12.8\%). In the case of organic pollutants, the worst pollutant exceeded the limits for $7.6 \%$ (PAU) of sites, BTEX cca 4.1\%, DDT 1.4\% and PCB cca 1.3\%. 